\title{
Effects of Building Configuration on Seismic Performance of RC Buildings by Pushover Analysis
}

\author{
Yasser Alashker'1, Sohaib Nazar², Mohamed Ismaiel ${ }^{2,3}$ \\ ${ }^{1}$ Structural Engineering Department, College of Engineering, Zagazig University, Zagazig, Egypt \\ ${ }^{2}$ College of Engineering, King Khalid University, Abha, Kingdom of Saudi Arabia \\ ${ }^{3}$ Cairo University, Cairo, Egypt \\ Email: sohaib.nazar@yahoo.com
}

Received 6 April 2015; accepted 19 May 2015; published 22 May 2015

Copyright (C) 2015 by authors and Scientific Research Publishing Inc.

This work is licensed under the Creative Commons Attribution International License (CC BY). http://creativecommons.org/licenses/by/4.0/

(c) ()

\begin{abstract}
In the recent earthquakes, concrete structures have been severely damaged or collapsed, which has raised questions against the seismic adequacy of existing buildings. These existing reinforced concrete buildings need to be evaluated to determine the capacity to resist seismic loads. The behavior of a building during earthquakes depends critically on its overall shape, size and geometry. Conventional approach to earthquake resistant design of buildings depends upon providing the building with strength, stiffness and inelastic deformation capacity which are great enough to withstand a given level of earthquake-generated force. This is generally accomplished through the selection of an appropriate building configuration and the careful detailing of structural members. In this research, nonlinear pushover analysis has been used to evaluate the seismic performance of three buildings with three different plans having same area and height. This method determines the base shear capacity of the building and performance level of each part of building under varying intensity of seismic force. The results of effects of different plan on seismic response of buildings have been presented in terms of displacement, base shear and plastic hinge pattern.
\end{abstract}

\section{Keywords}

Pushover Analysis, Seismic Performance, Base Shear, Building Configuration

\section{Introduction}

An earthquake is the vibration of the earth's surface that follows a sudden release of energy in the crust. Ground

How to cite this paper: Alashker, Y., Nazar, S. and Ismaiel, M. (2015) Effects of Building Configuration on Seismic Performance of RC Buildings by Pushover Analysis. Open Journal of Civil Engineering, 5, 203-213.

http://dx.doi.org/10.4236/ojce.2015.52020 
surface moves in all directions during earthquake. The most devastating effects on buildings are caused by lateral movements which disturb the stability of the structure, leading to collapse sideways. Since buildings are normally constructed to resist gravity loads, many conventional systems of construction are not inherently resistant to horizontal forces. Strengthening of such buildings have been proved as more economical and viable immediate shelter solution rather than replacement of buildings [1].

These vulnerable buildings to damage need to be identified and an acceptable level of safety must be determined. To make such evaluation, pushover analysis which is a nonlinear method performance based method has been developed by structural engineers. Pushover analysis determines expected seismic performance of structural system by estimating its strength and deformation demands in design earthquake. Also this method determines the capacity curve for the building based on series of incremental static analysis. Based on this capacity curve, a targeted displacement (an estimation of design displacement during earthquake) is determined. In recent researches, capacity spectrum method (CSM), the displacement coefficient method (DCM) and modal pushover analysis (MPA) have been used to evaluate the performance of the buildings [2].

In modern world, challenges for structural engineer increased due to various types of irregularities involve in the buildings as designed by the architects. In more slendrical buildings, the horizontal movement of the floors increases significantly which may lead to increment in drift and overturning effects of the earthquake. Therefore, damaging effects are more in short but long buildings during earthquake shaking. Generally, seismic calculations are done by assuming ground as a solid elastic base under the building. This assumption is applicable in buildings with small plan area. However, chances for differential settlement of foundations in buildings with long plan increase due to uneven shaking of different parts [3]. The inertia force produced during earthquake tends to transfers to foundation through lateral resisting slabs in proportion to their stiffness. Also slabs in long plan buildings tend to bend to their plane direction, which may lead to overstressing of slabs then their capacities. Consequently, it disturbs the rigid diaphragm action of slabs causing undue displacement as shown in Figure 1. Therefore, it is undesirable to have buildings with large plan size [4].

In this paper, four buildings have been analysed with different plans of aspect ratio of 1, 1.5, 2 and 4 having the same area. The results are compared in terms base shear, displacement and plastic hinge pattern to evaluate the effects of different plan aspect ratio on the performance level of buildings. The study shows that hinges have developed in the beams and columns showing the three stages IO (immediate occupancy), LS (life safety) and $\mathrm{CP}$ (collapse prevention) as shown in Figure 2.

\section{Pushover Analysis}

Static pushover analysis is an attempt by the structural engineers to evaluate the real strength of the structure and it promises to be a useful and effective tool for performance based design. In pushover analysis; building is subjected to incremental lateral loads at different levels representing the inertial forces due to ground shaking during earthquake. Consequently, at each increment some elements of structure may yield due to loss of stiffness as shown in Figure 2. The sequence of crack propagation, plastic hinge formation and yielding of structural elements of the building are recorded with respect to incremental lateral loads. The ATC-40 [5] and FEMA-356 [6]

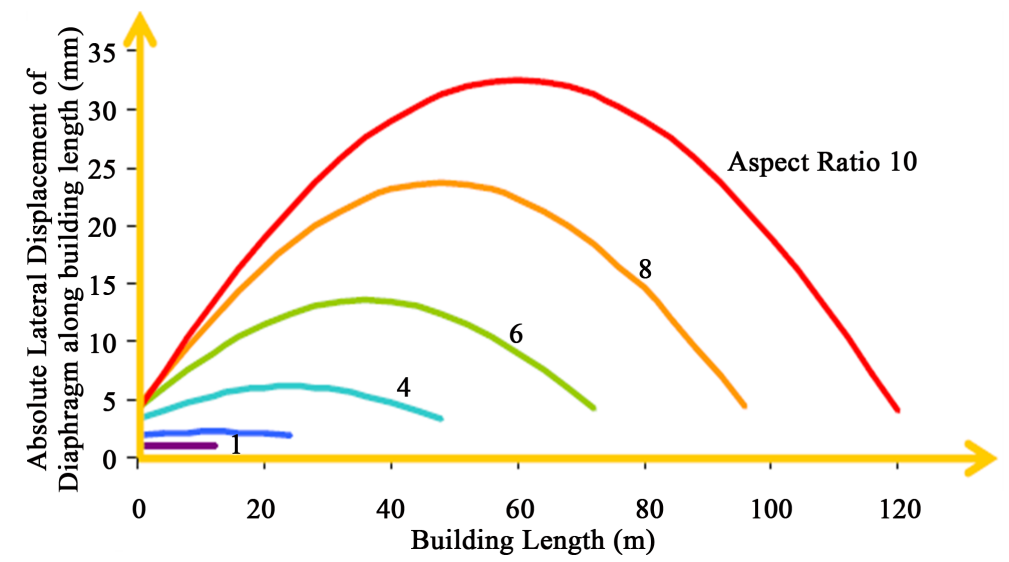

Figure 1. Lateral displacement of diaphragm [4]. 


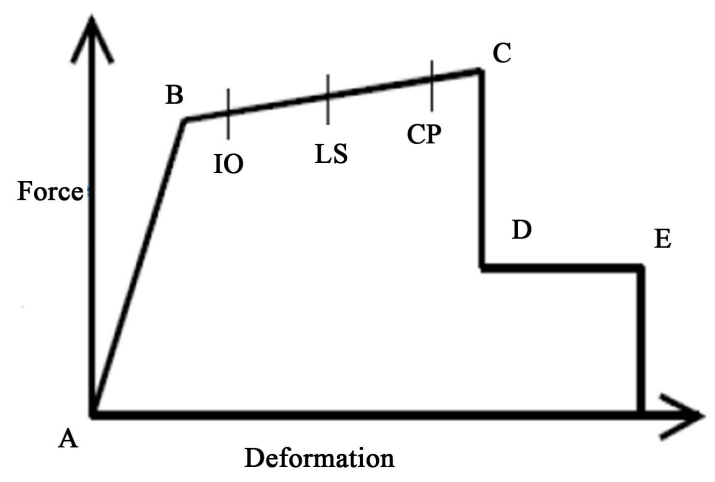

Figure 2. Load deformation curve [9].

documents have developed modeling parameters, acceptance criteria and procedures of pushover analysis. Pushover analysis significantly evaluates the expected performance level of the structural system by the capacity curve of the building. Based on this capacity curve, target displacement is estimated which is expected to be produced during the earthquake. Also analysis enables to determine the collapse load and ductility capacity. The output of the analysis can better be explained by demand versus capacity curve. In Figure 3, demand curve intersects the capacity curve in elastic range which shows the good resistance level of the building. However, in Figure 4 the intersection of demand curves to capacity curve outside the elastic range, which shows the poor performance level of the building [7] [8].

\section{Description of Model}

Four cases of residential building with plan aspect ratio of 1, 1.5, 2 and 4 are considered for study as shown in Figures 5-8. The buildings are composed of moment resisting RC frame with solid slab, $140 \mathrm{~mm}$ thickness, situated in zone 3 . The structure members are made of in-situ reinforced concrete. The overall plan dimensions are $20 \mathrm{~m} \times 20 \mathrm{~m}, 25 \mathrm{~m} \times 16 \mathrm{~m}, 28.5 \mathrm{~m} \times 14 \mathrm{~m}$ and $40 \mathrm{~m} \times 10 \mathrm{~m}$ having same area of $400 \mathrm{~m}^{2}$. The buildings are five-story with height of $15.2 \mathrm{~m}$. Columns and beams sizes are $500 \times 300 \mathrm{~mm}$ and have been modelled as frame elements while in-plane rigidity of the slab is simulated using rigid diaphragm action. The columns are assumed to be fixed at the base. The building is analyzed as per seismic provisions provided by UBC-1997 [10]. The seismic load according to the relevant code has been estimated and the building is analyzed for combined effect of gravity and seismic loads as shown in Table 1, considering all the design load combinations specified in code. SAP2000 [11] finite element software is utilized for three dimensional modeling and analyses of the buildings. Moreover, these models have been analyzed for seismic zoning $\mathrm{Z}=0.3$, with occupancy category $\mathrm{I}=1$, and site class $\mathrm{S}_{\mathrm{D}}$.

\section{Seismic Loads on the Building}

The total design base shear according to UBC-1997 along any principal direction can be calculated by following equation [12] [13].

$$
V=\frac{C v I}{R T} \cdot W
$$

The maximum total base shear will be taken as the following:

$$
V=\frac{2.5 C_{a} I}{R} \cdot W
$$

The minimum total base shear will be taken as the following:

$$
V=0.11 I \cdot C_{a} \cdot W
$$

The approximate fundamental period (T), in seconds, is determined from the following equation:

$$
T=C_{t} \cdot h_{n}^{3 / 4}
$$




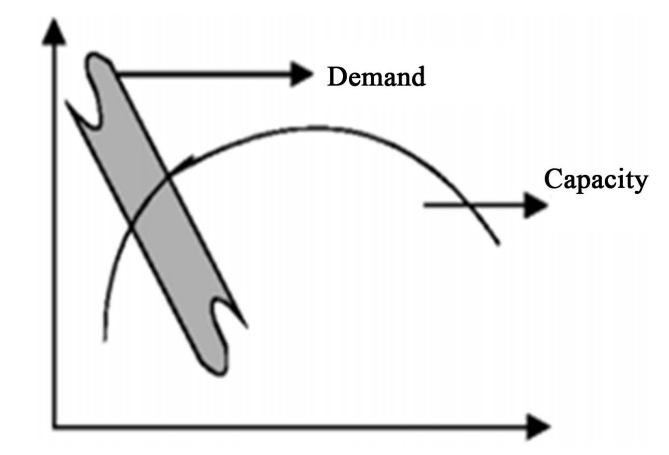

Figure 3. Safe design.

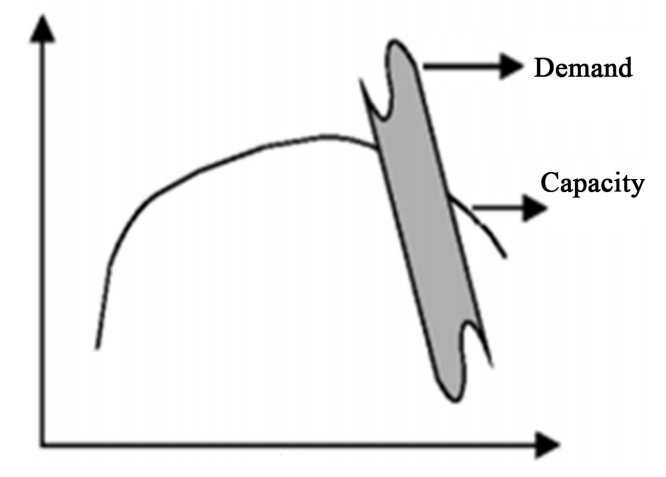

Figure 4. Unsafe design [7].

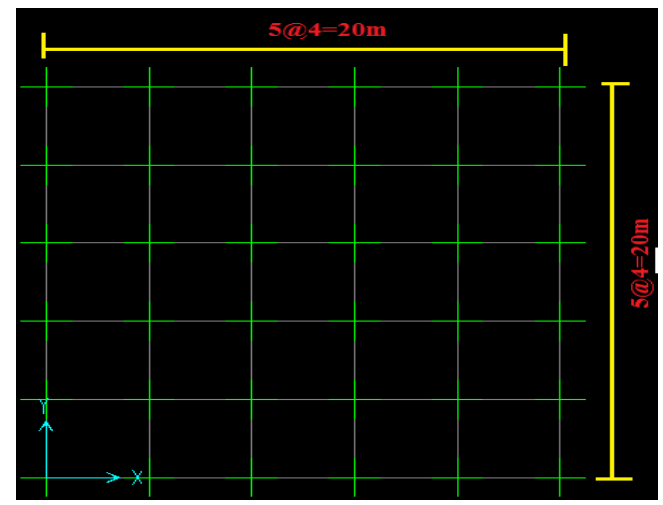

Figure 5. (Case 1) plan of the building with aspect ratio 1.

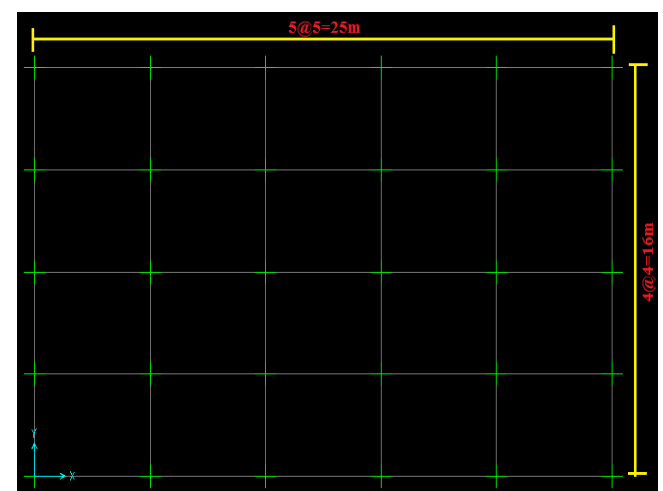

Figure 6. (Case 2) plan of the building with aspect ratio 1.5. 


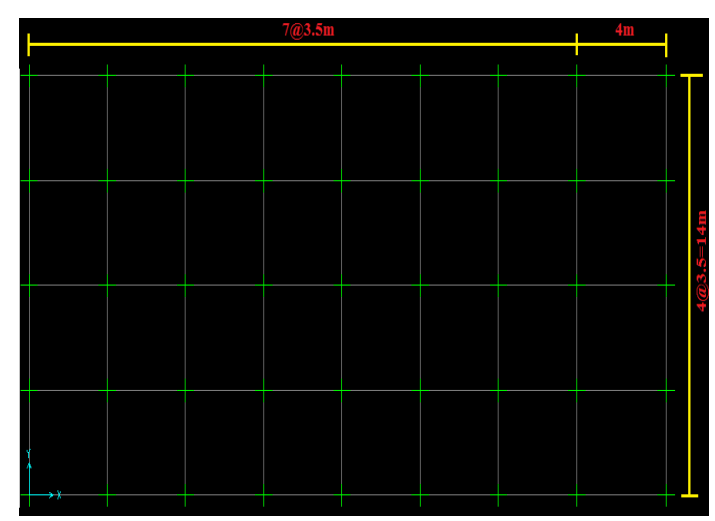

Figure7. (Case 3) plan of the building with aspect ratio 2.

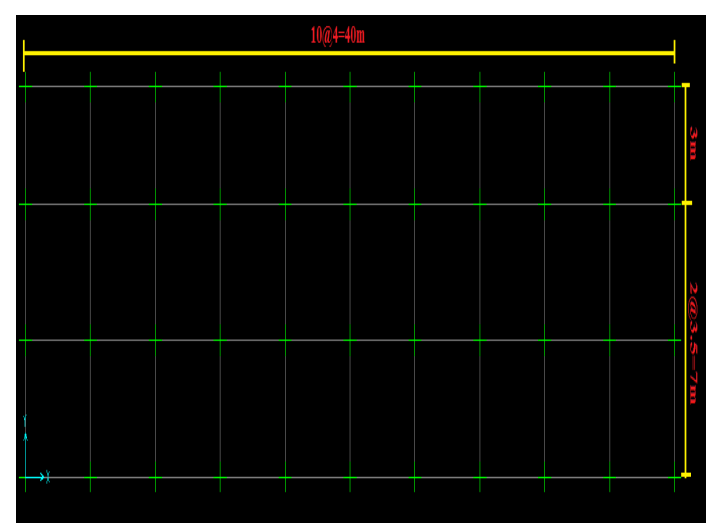

Figure 8. (Case 4): plan of building with aspect ratio 4 .

Table 1. Gravity loads on building.

\begin{tabular}{cc} 
& Dead Loads \\
\hline Water Proofing & $2.5 \mathrm{KN} / \mathrm{m}^{2}$ \\
Super Imposed Load on Roof & $1 \mathrm{KN} / \mathrm{m}^{2}$ \\
Floor Finish & $1 \mathrm{KN} / \mathrm{m}^{2}$ \\
Partitions & $3 \mathrm{KN} / \mathrm{m}^{2}$ \\
Live Loads & \\
On Roof & $1 \mathrm{KN} / \mathrm{m}^{2}$ \\
On Floors & $3 \mathrm{KN} / \mathrm{m}^{2}$ \\
\hline
\end{tabular}

where:

$V=$ total base shear.

$W=$ total seismic weight of the building.

$R=$ the response modification factor.

$I=$ the occupancy importance factor.

$h_{n}=$ is the height in (m).

$C_{a}$ and $C_{v}$ are acceleration and velocity based seismic co-efficients respectively.

$C_{t}=0.035$ (0.0853) for steel moment-resisting frames.

$C_{t}=0.030(0.0731)$ for reinforced concrete moment-resisting frames and eccentrically braced frames. 
$C_{t}=0.020$ (0.0488) for all other buildings.

The base shear shall be distributed over the height of the structure, including Level $n$, according to the following formula:

$$
F_{x}=\frac{\left(V-F_{t}\right) w_{x} \cdot h_{x}}{\sum_{i=1}^{n} w_{i} \cdot h_{i}}
$$

where:

$F_{t}=0.07 \mathrm{~T} V<0.25 \mathrm{~V}$; when: $T \leq 0.7 \mathrm{sec}$.

$F_{X}=$ the lateral seismic force at any level $(\mathrm{KN})$.

\section{Results}

\subsection{Base Shear versus Top Displacement}

All four buildings were analysed in both $\mathrm{X}$ and $\mathrm{Y}$ directions for static nonlinear (pushover) analysis using SAP2000. The Base shear versus displacement graphs have been plotted and compared for all models. The results show the highest values in X direction. Maximum base shear has been found in Case 4 (building with plan aspect ratio of 4). However, Case 2 shows the least value of base shear in both directions as shown in Figure 9 and Figure 10. Moreover, displacement value has been found same in first three cases except the Case 4 where results show the maximum displacement in $\mathrm{X}$ direction. In addition to, all four models show more ductile behavior in $\mathrm{X}$ direction.
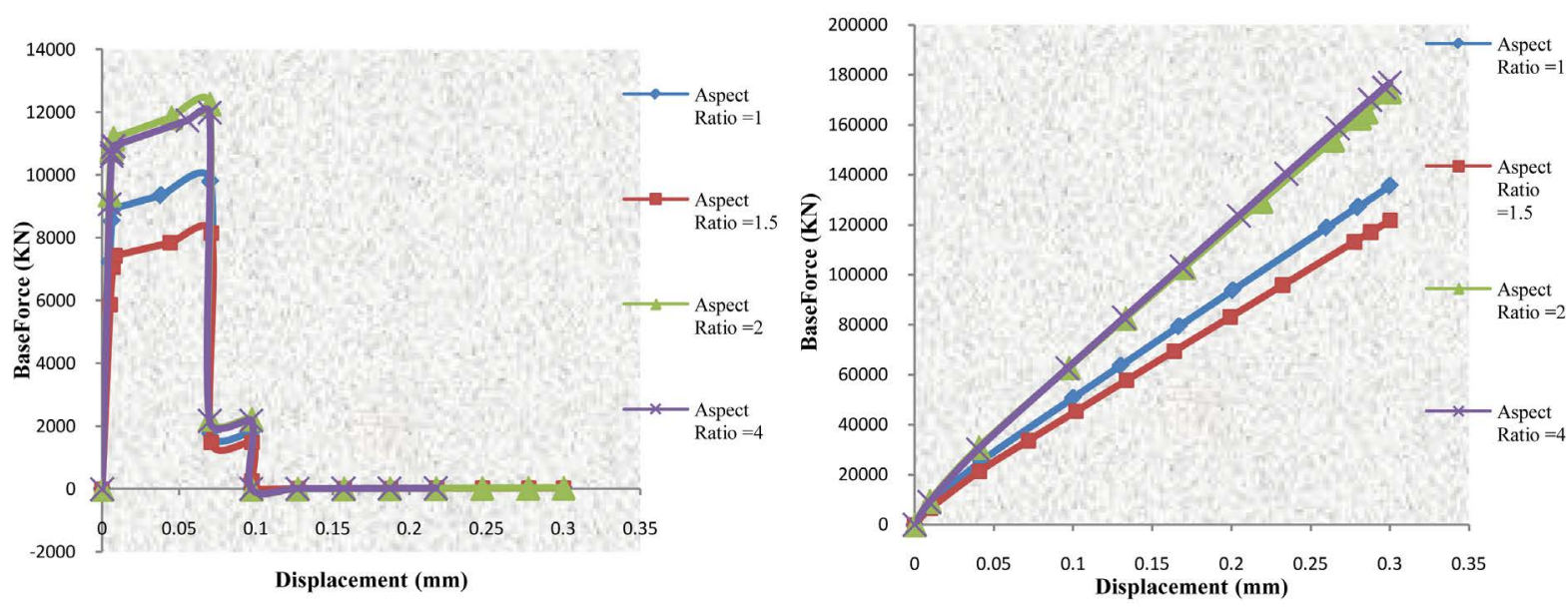

Figure 9. Comparison of base force versus displacement in X \& Y-directions.
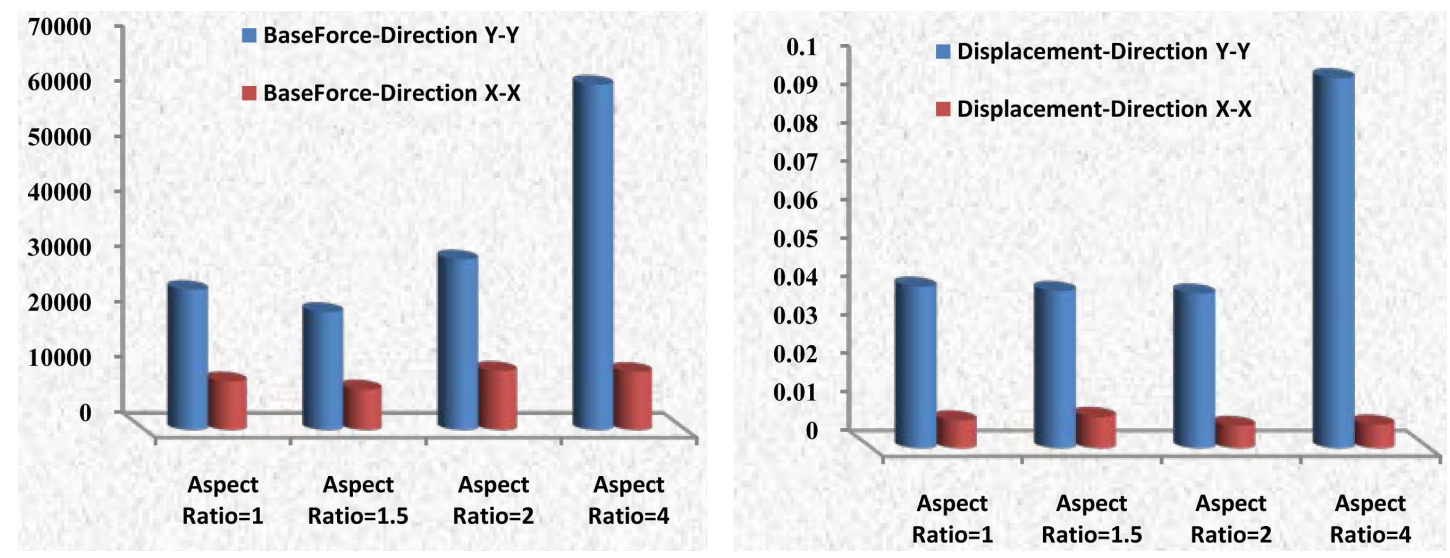

Figure 10. Comparison of base force in $\mathrm{X} \& \mathrm{Y}$ directions. 


\subsection{The Performance Point}

It is the point where the capacity curve crosses the demand curve according to ATC-40 as shown in Figure 11. Figures 12-15 shows the performance point in both directions for all push over curves, with the red colour is the elastic spectrum, the green curve represents the spectrum resistant and the yellow line defines the point as defined by ATC-40.The intersection of the yellow line (demand) and the green curve (capacity) is the performance point. Case 2 (building with plan aspect ratio 1.5) showed the better performance point at low value of spectral acceleration and least number of hinges in both directions. Also the performance point has been found in step 3 before CP (collapse prevention at step 7) which ensures the safe design of the building. Thereafter, the number of hinges increases with increase in plan aspect ratio, with Case 4 showing the most number of hinges at performance point as shown in Figures 20-23.

\subsection{Yielding (Plastic Hinge) Pattern of the Structure at the Performance Point}

Plastic hinge formation for all four buildings models have been obtained at different displacement levels. The hinging patterns are plotted in Figures 16-19. Comparison of these figures shows the quite similarity of hinging

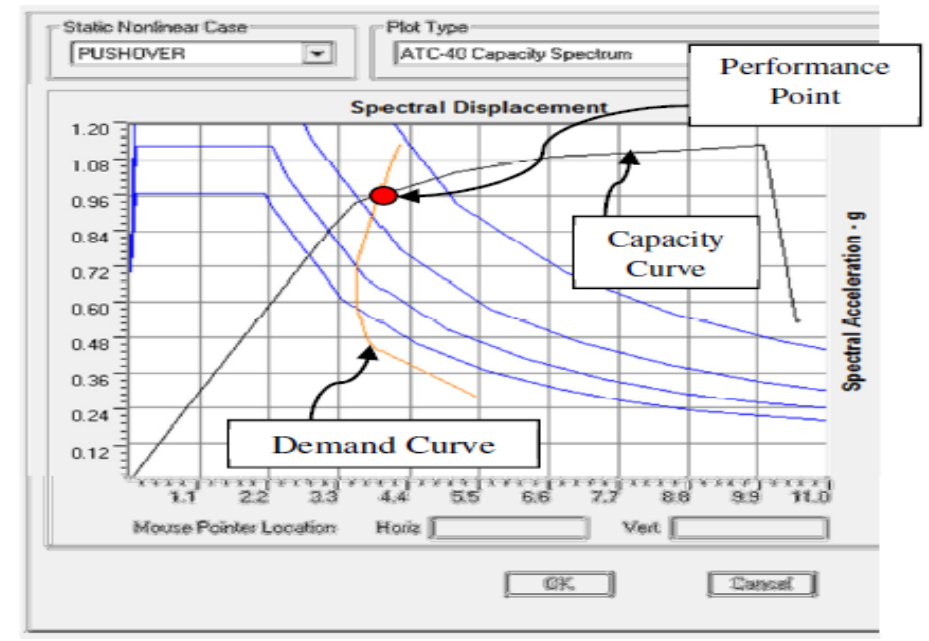

Figure 11. The performance point.

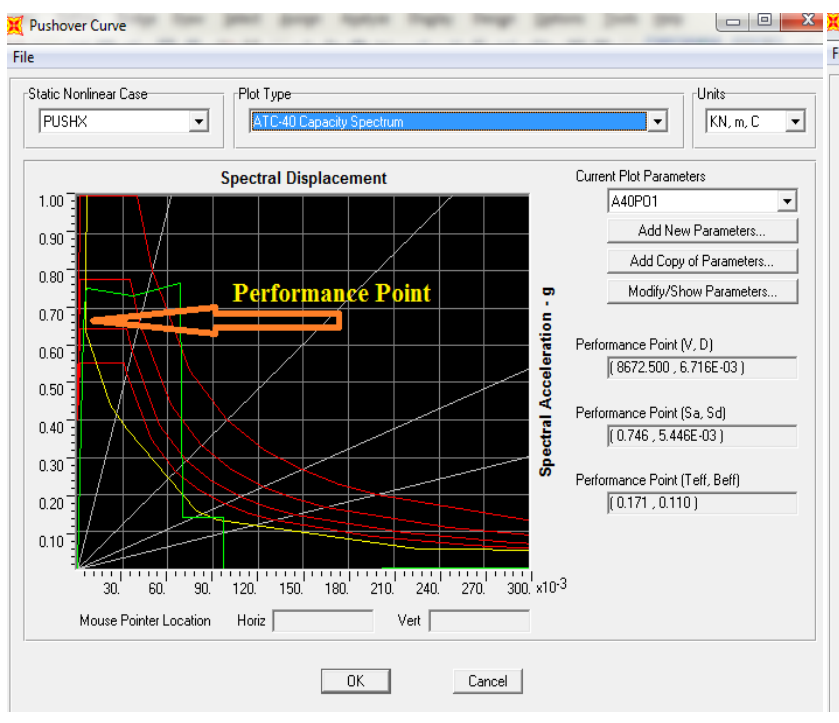

Case 1

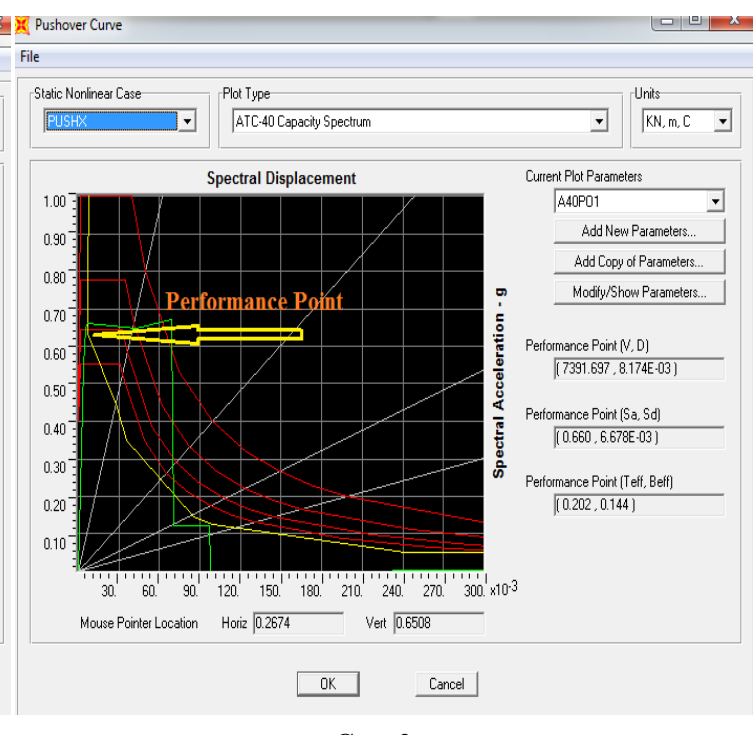

Case 2

Figure 12. Pushover capacity curve and performance point (X-Dir). 

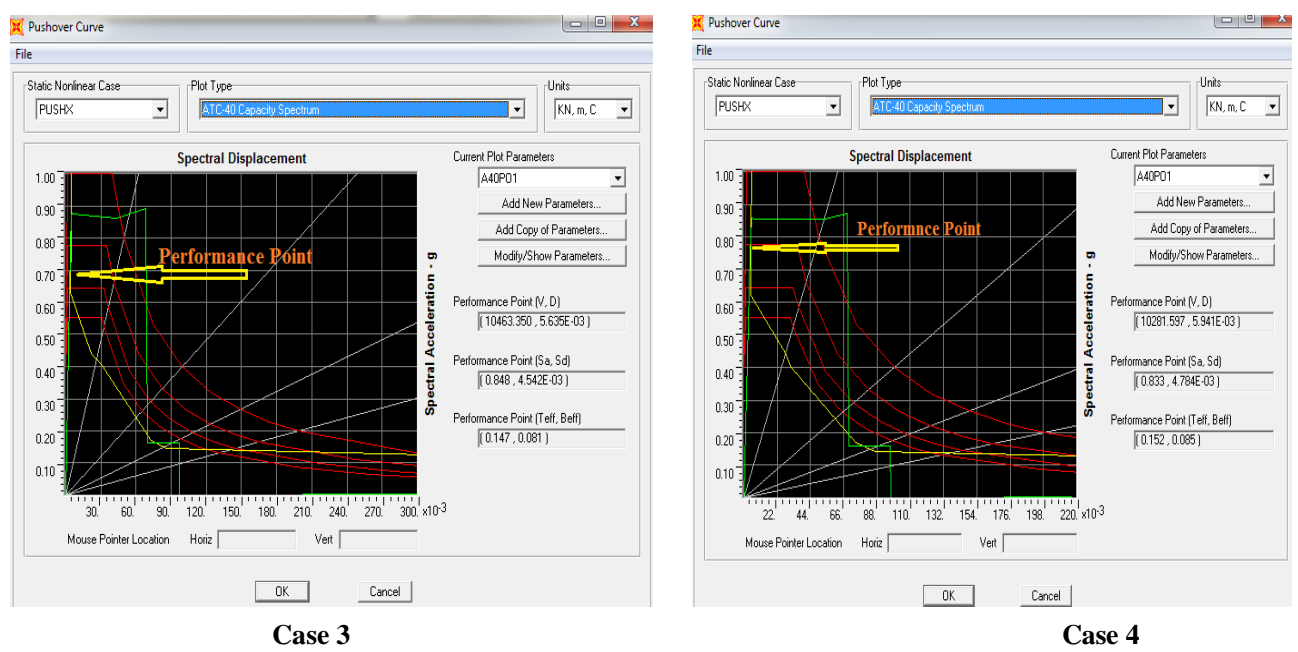

Case 3

Case 4

Figure 13. Pushover capacity curve and performance point (X-dir).

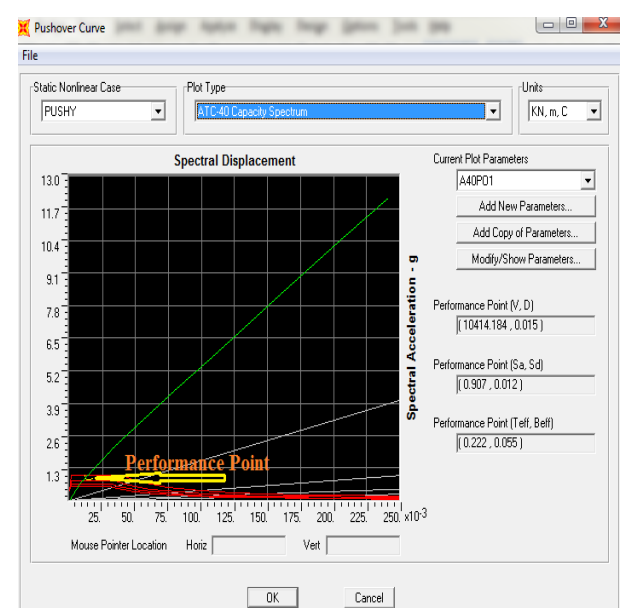

Case 1

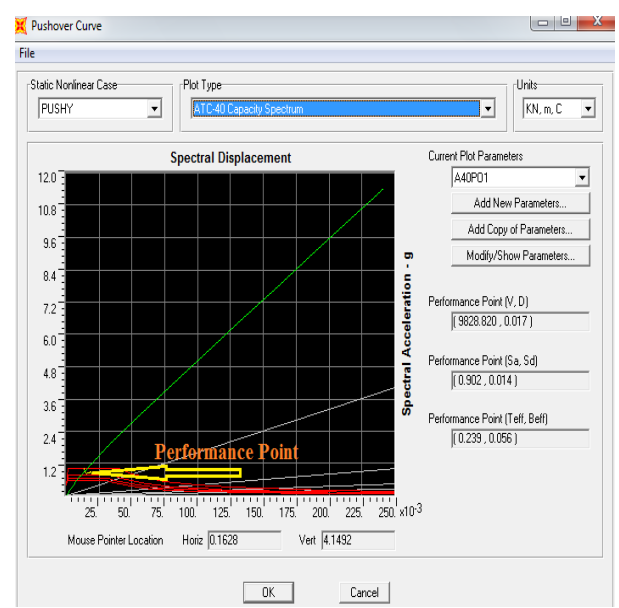

Case 2

Figure 14. Pushover capacity curve and performance point (Y-dir).

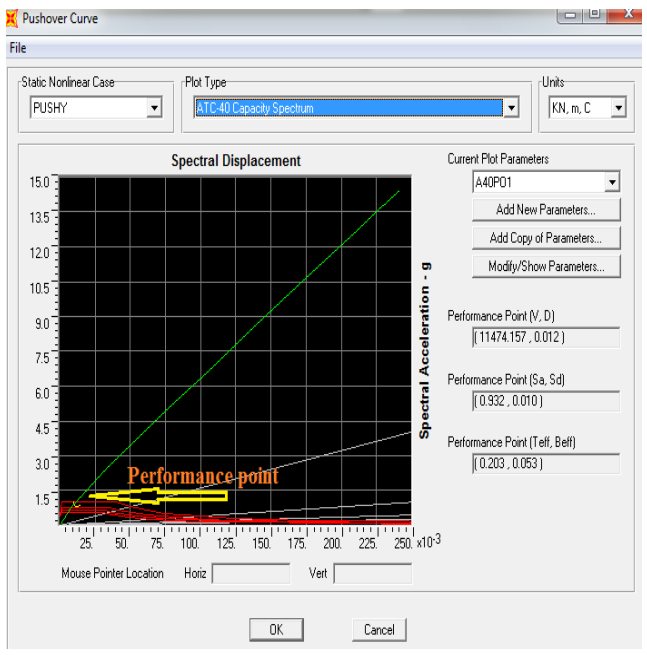

Case 3

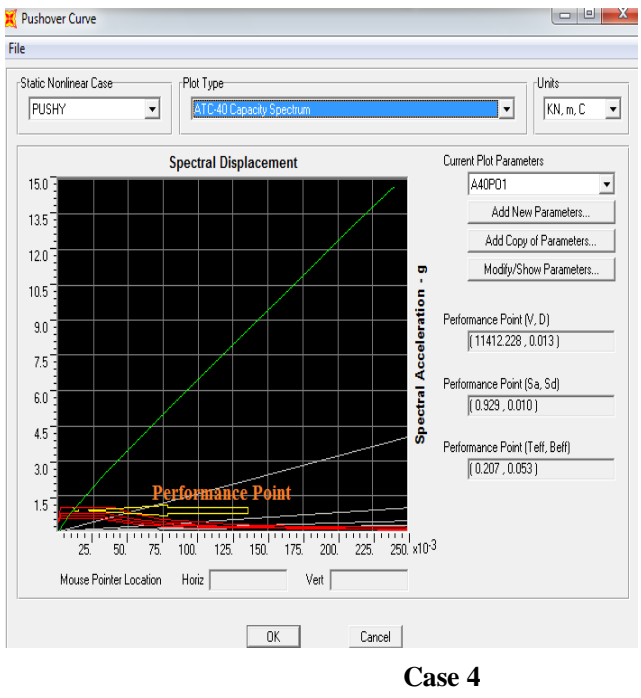

Figure 15. Pushover capacity curve and performance point (Y-dir). 

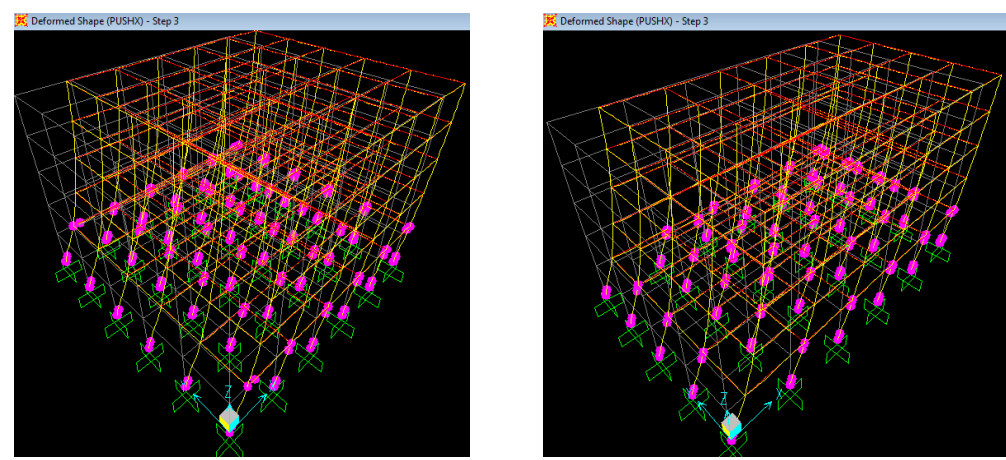

Figure 16. (Case 1 \& Case 2) yielding pattern of the structure at the performance point (X-dir).
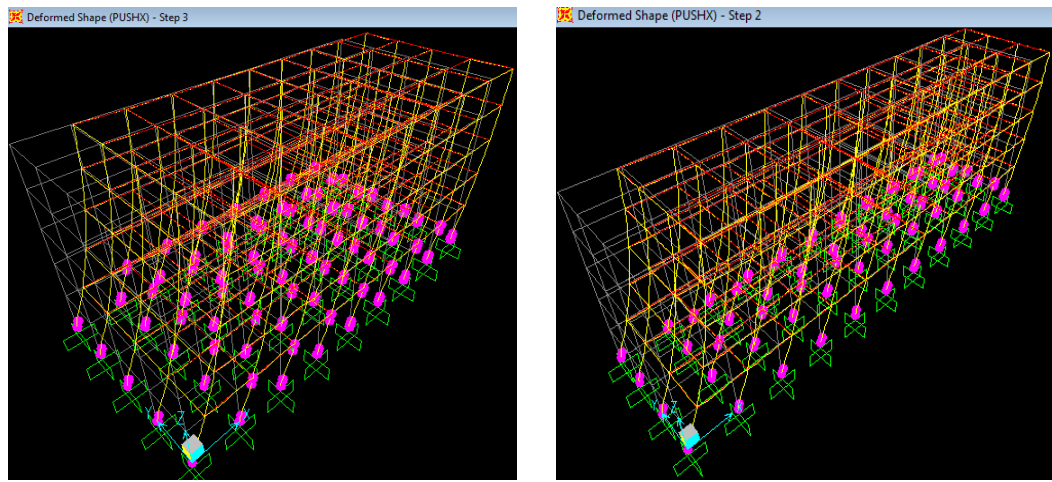

Figure 17. (Case 3 \& Case 4) yielding pattern of the structure at the performance point (X-dir).
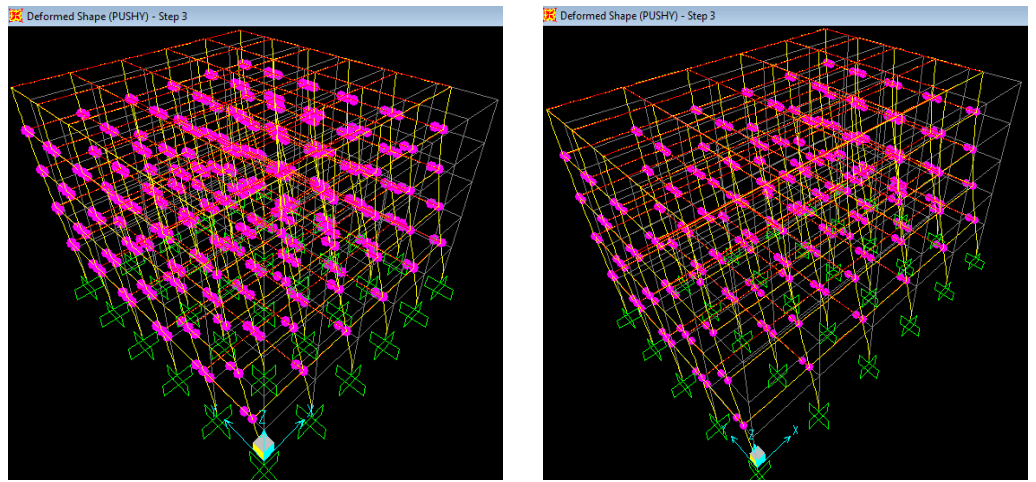

Figure 18. (Case 1 \& Case 2) yielding pattern of the structure at the performance point (Y-dir).
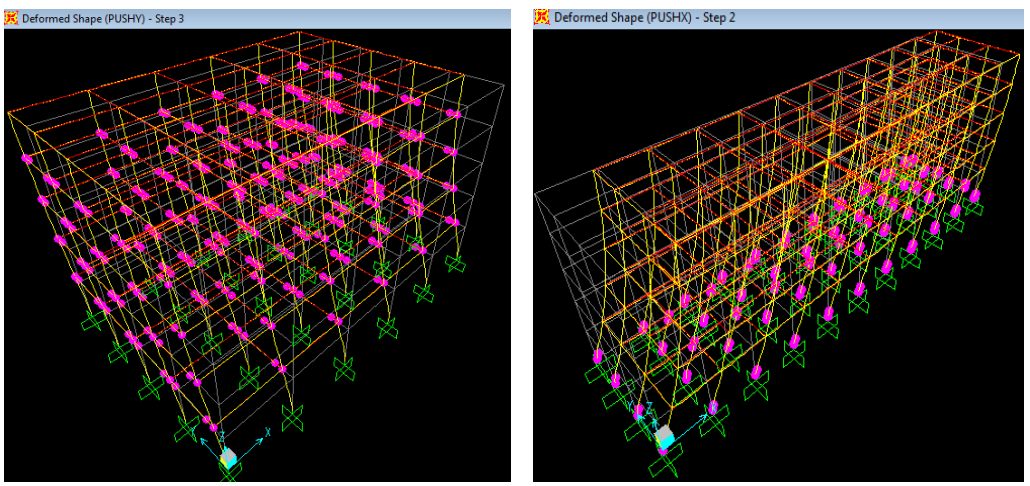

Figure 19. (Case 3 \& Case 4) yielding pattern of the structure at the performance point (Y-dir). 
pattern. Plastic hinge formation starts with the yielding of structural members of lower stories and then propagates to upper stories with yielding of intermediate columns. Case 2 shows the better performance of building in both directions with least number of hinges formed at performance point. However, Case 4 shows the most number of hinges at performance point as shown in Figures 20-22. Moreover, number of hinges formed at different levels of performance of building increases with increase in plan aspect ratio. Figures 20-22 shows the number of plastic hinges formed due to yielding of members, at different level of performance in $\mathrm{X}$ and $\mathrm{Y}$ directions. Also the analysis results showed the limited damage in four buildings due to yielding occurred at events B, IO and LS respectively.

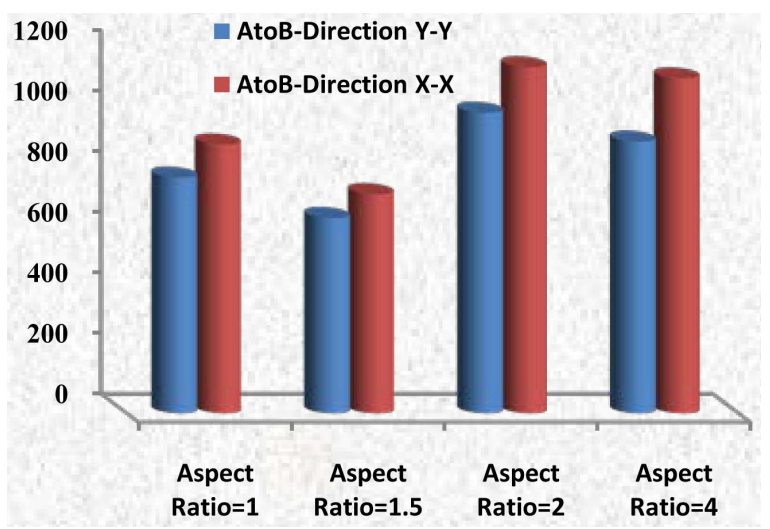

Figure 20. Number of plastic hinges from A to B.

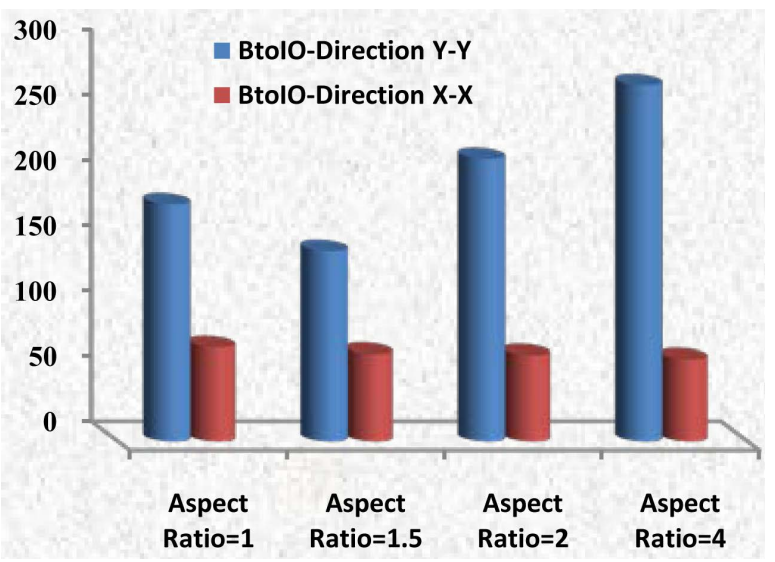

Figure 21. Number of plastic hinges from B to IO.

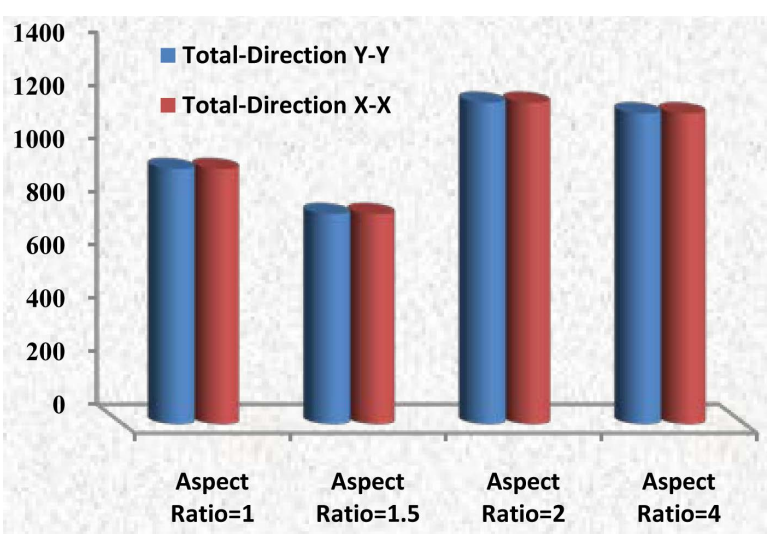

Figure 22. Total number of Plastic hinges from in X \& Y directions. 


\section{Conclusions}

Static pushover analysis is an attempt by the structural engineers to evaluate the real strength of the structure. This method of analysis promises to be a useful and effective tool for performance based design of structure. Four residential buildings with different plan aspect ratio have been analyzed by this method and results have been compared in terms of base shear, displacement and, plastic hinge pattern. From this study, following conclusions can be drawn.

1) Pushover analysis has been found relatively simple and evaluates the performance of the building close to more realistic behavior.

2) The plan dimensions significantly influence the seismic behavior of the buildings.

3) The building with plan aspect ratio 1.5 shows the least base shear in both directions, thereafter base shear significantly increases with increase in plan aspect ratio.

4) The inter story drift is relative displacement of one story relative to story below. It significantly increases in Case 3 and Case 4 with increase in plan aspect ratio.

5) Increasing plan aspect ratio makes the $Y$ direction of building more vulnerable to damage during earthquake.

6) By increasing plan aspect ratio, the total number of hinges formed at different performance levels also increases, which may lead to building deficiency of resisting seismic loads.

7) Ductility is one of the most important factors affecting the building performance. Thus, earthquake-resistant design strives to determine the plan dimensions to ensure ductile behaviour of the building.

8) Finally, the architect and engineer should both employ ingenuity and imagination of their respective disciplines to reduce the effect of irregularities, or to achieve desired aesthetic qualities without compromising structural integrity.

\section{References}

[1] Pankaj A. and Manish S. (2006) Earthquake Resistant Design of Structures, ISBN-81-203-2892-2. Prentice Hall of India (pvt), New Delhi, 534-540.

[2] Kadid, A. and Boumrkik, A. (2008) Pushover Analysis of Reinforced Concrete Frame Structures, Asian Journal of Civil Engineering (Building and Housing), 9, 75-83.

[3] Solomon, A. and Hemalatha, G. (2013) Limitations of Irregular Structure for Seismic Response. International Journal of Civil and Structural Engineering, 3, 579.

[4] Murty, C.V.R., Goswami, R., Vijayanarayanan, A.R. and Mehta, V. (2012) Earthquake Behavior of Buildings. Gujarat State Disaster Management Authority, Gandhinagar, 53-79.

[5] Federal Emergency Management Agency, FEMA-356 (2000) Prestandard and Commentary for Seismic Rehabilitation of Buildings, Washington DC.

[6] Applied Technology Council, ATC-40 (1996) Seismic Evaluation and Retrofit of Concrete Buildings, Vols. 1 and 2 , California.

[7] Poluraju, P. and Nageswara, R. (2011) Pushover Analysis of Reinforced Concrete Frame Structure Using SAP 2000, International Journal of Earth Sciences and Engineering, 4, 684-690.

[8] Ismaeil, M.A. (2014) Pushover Analysis of Existing 3 Stories RC Flat Slab Building in the Sudan. Joint International Conferences 2014, Pattaya, 8-9 November 2014, Paper ID-ICRTIST-2014-5092.

[9] Habibullah, A. and Pyle, S. (1998) Practical Three Dimensional Nonlinear Static Pushover Analysis. Structure Magazine.

[10] UBC-1997 (1997) Structural Design Requirements. Vol. 2, International Conference of Building Officials, Whittier.

[11] Computers and Structures (2001) SAP2000 Three Dimensional Static and Dynamic Finite Element Analysis and Design of Structures. Computers and Structures Inc., Berkeley.

[12] Alashker, Y., Nazar, S. and Ismaeil, M.A. (2014) A Comparative Study of Seismic Strengthening of RC Buildings by Steel Bracings and Concrete Shear Walls. International Journal of Civil and Structural Engineering Research, 2, 2434.

[13] Nazar S. (2014) A Comparative Study of Seismic Provisions Provided in UBC-97 and Saudi Building Code. World Academy of Science, Engineering and Technology, International Journal of Civil Science and Engineering, 10, 448454. 